\title{
Kształcenie humanistyczne w nowej rzeczywistości społeczno-medialnej
}

\section{Humanistic education in the social-media new reality}

\author{
\#Elżbieta Winiecka
Uniwersytet im. Adama Mickiewicza w Poznaniu
}

\begin{abstract}
The article presents the perspective of modern education in Polish philology studies. The author discusses selected challenges of contemporary Polish philology academic education. As the example, the author characterizes the educational program of two specializations: Media Communication and Digital Media and Culture, implemented in the Institute of Polish Philology, Adam Mickiewicz University. She points also to the need to broaden the professional competence of students of Polish philology. These could be skills in other disciplines of the humanities and new technologies. In this way both specializations refers to the idea of digital humanities (DH) which is a scholarly activity at the intersection of computer technology and the disciplines of the humanities.
\end{abstract}

Key words: Polish philology, vocational training at the university, Media Communication, Digital Media and Culture, digital humanities

Streszczenie: Artykuł prezentuje perspektywy kształcenia współczesnych polonistów. Autorka na przykładzie programu dwóch specjalizacji: komunikacji medialnej i kultury mediów cyfrowych, realizowanych w Instytucie Filologii Polskiej UAM, omawia wybrane wyzwania współczesnej polonistycznej edukacji akademickiej. Wskazuje na potrzebę poszerzenia kompetencji zawodowych studentów filologii polskiej o umiejętności z zakresu innych dyscyplin humanistycznych i nowych technologii. Odwołuje się w ten sposób do idei humanistyki cyfrowej.

Słowa kluczowe: filologia polska, kształcenie zawodowe na uniwersytecie, komunikacja medialna, kultura mediów cyfrowych, humanistyka cyfrowa.

\section{Polonistyczne fundamenty}

Od wielu lat Instytut Filologii Polskiej UAM oferuje swoim studentom poszerzenie standardowego wykształcenia polonistycznego o kompetencje komunikacyjno-medialne. Podnoszą one atrakcyjność absolwentów wydziałów humanistycznych na współczesnym rynku pracy. Kompetencje te rozwijane są w ramach dwóch specjalizacji, realizowanych na obu stopniach studiów. Na studiach licencjackich jest to komunikacja medialna, na 
studiach magisterskich kultura mediów cyfrowych. Obie pomyślane jako spójny projekt, zaplanowane zostały jednak tak, aby student mógł skorzystać z alternatywnych ścieżek kształcenia. Może realizować obie specjalności kolejno albo wybrać tylko jedną z nich. Programy obu - kształcąc absolwenta o określonym typie zainteresowań i umiejętności - funkcjonują jako samodzielne oferty edukacyjne. $\mathrm{W}$ ten sposób wybierając na pierwszym stopniu komunikacje medialną (jako specjalizację podstawową lub uzupełniającą), po trzech latach absolwent jest licencjatem przygotowanym do pracy w branży PR, reklamie i marketingu. Może też rozwijać swoje zainteresowania na drugim stopniu studiów. Wybierając tutaj kulture mediów cyfrowych, wchodzi na obszar rozległej interdyscyplinarnej dziedziny humanistyki cyfrowej, w której zgłębia związki wiedzy humanistycznej z najnowszymi technologiami. Jeśli specjalizację tę realizuje równolegle z nauczycielską - staje się dodatkowo ekspertem w dziedzinie wiedzy o mediach i edukacji medialnej.

\section{Stopień pierwszy: specjalista branży PR, reklamy i marketingu}

Proponowana na studiach pierwszego stopnia specjalizacja komunikacja medialna adresowana jest do studentów dopiero rozpoczynających edukację polonistyczną. Uzupełnia program kształcenia o przedmioty i zajęcia warsztatowe, które funkcjonalizują zdobywaną w trakcie kształcenia polonistycznego wiedzę i wyposażają uczestników zajęć w umiejętności przydatne w pracy przede wszystkim w branży reklamy, marketingu, brandingu oraz PR. Warto podkreślić, że - zgodnie z raportem Polskiej Agencji Rozwoju Przedsiębiorczości opublikowanym w roku 2014 - najbardziej pożądane przez pracodawców u kandydatów do pracy są kompetencje miękkie, na których deficyt narzekają oni najczęściej․ Warto przy tym dodać, że porozumiewanie się w języku ojczystym zaliczone zostało przez autorów badań (za instytucjami unijnymi) do twardych kompetencji kluczowych. Definiuje się je jako

zdolność wyrażania i interpretowania pojęć, myśli, uczuć, faktów i opinii w mowie i piśmie (rozumienie ze słuchu, mówienie, czytanie i pisanie) oraz językowej interakcji odpowiedniej i kreatywnej formie w pełnym zakresie kontekstów społecznych i kulturowych ${ }^{2}$.

Program specjalizacji komunikacja medialna kładzie zatem nacisk zwłaszcza na doskonalenie umiejętności komunikacyjnych w mowie i piśmie, by wraz z wiedzą o języku i mediach wzrastała komunikatywność przyszłych pracowników branży reklamowej i PR. Ceniona na rynku pracy umiejętność pracy w grupie, kreatywność, samodzielność, elastyczność oraz umiejętne zarządzanie czasem, planowanie i rozwiązywanie problemów, ćwiczone są podczas zajęć warsztatowych, podczas których studenci

\footnotetext{
1 Por. Kompetencje Polaków a potrzeby polskiej gospodarki. Raport podsumowujacy IV edycje badań BKL z 2013 r., 2014, Górniak J. (red.), Warszawa.

${ }^{2}$ Cyt za: Kompetencje Polaków a potrzeby polskiej gospodarki, s. 183.
} 
nie tylko zdobywają praktyczne umiejętności, ale poznają własne mocne strony. Budują w ten sposób swoją świadomość jako kompetentnych kandydatów na rynku pracy. Na ten aspekt wzmacniania u studentów poczucia własnej wartości oraz świadomości tego, co potrafią, warto kłaść szczególny nacisk. Młodzi ludzie często bowiem nie wiedzą, jak wiele umiejętności (właśnie tych nazywanych przez pracodawców miękkimi) zdobywają w trakcie studiów uniwersyteckich.

Program specjalizacji obejmuje 330 godzin warsztatów, ćwiczeń i wykładów realizowanych przez cztery semestry. Zajęcia prowadzone są przez pracowników Instytutu Filologii Polskiej. Blok zajęć poświęconych komunikacji językowej, reklamie i copywritingowi realizują przede wszystkim doświadczeni wykładowy i praktycy z Zakładu Frazeologii i Kultury Języka Polskiego. Blok zajęć z zakresu współczesnej kultury i mediów prowadzą pracownicy Zakładu Literatury i Kultury Nowoczesnej, na co dzień zajmujący się badaniami nad problemami komunikacji w kulturze popularnej oraz w środowisku cyfrowym. Warsztaty z zakresu komunikacji reklamowej oraz marketingu realizowane są przez doświadczonych praktyków współpracujących z Instytutem Filologii Polskiej, w tym przez specjalistów Działu Promocji i Marketingu UAM.

\section{Kultura medialna - siatka zajęć}

Student rozpoczyna kształcenie zawodowe od poznania reguł obowiązujących w komunikacji (Teoretyczne podstawy komunikacji językowej). Taka specjalistyczna wiedza przydaje mu się, kiedy staje przed koniecznością dobrania właściwych środków do tego, by osiągnąć zamierzony komunikacyjny cel. Wykład obfituje w liczne przykłady praktycznych rozwiązań problemów komunikacyjnych. Na zaczerpniętych „z życia” próbkach niefortunnych zdarzeń komunikacyjnych omówione zostają najczęściej popełniane błędy, które obniżają skuteczność porozumiewania się. W tym samym semestrze studenci uczestniczą w warsztacie, na którym uczą się, jak tworzyć skuteczne hasła reklamowe (Jezzykowe podstawy copywritingu). $\mathrm{Na}$ ćwiczeniach z Semiotyki kultury uczą się z kolei krytycznego odczytywania przekazów werbalnych, wizualnych, audiowizualnych oraz multimedialnych, z uwzględnieniem właściwości użytych środków przekazu i sytuacji komunikacyjnej.

W następnej kolejności słuchacze otrzymują porcję wiedzy z zakresu rozwoju mediów i ich kulturotwórczej roli (Historia i teoria mediów). Budowana $\mathrm{w}$ ten sposób świadomość rangi i znaczenia kolejno pojawiających się technologii komunikacyjnych (pismo, druk, radio, telewizja, komputer, Internet) zostaje dopełniona wiedzą na temat narodzin, rozwoju i właściwości kultury popularnej (Wprowadzenie do kultury popularnej). Zdobyte kompetencje studenci wykorzystują $\mathrm{w}$ praktyce podczas zajęć z podstaw tworzenia i krytyki tekstów kultury popularnej (Czytanie 
kultury popularnej). Tak zorganizowany blok zajęć ma przede wszystkim przygotować uczestników do spotkań warsztatowych, które odbywają się na następnym etapie kształcenia.

Pierwszy z trzech warsztatowych cykli (Wybrane aspekty autoprezentacji) poświęcony jest trenowaniu zdolności panowania nad własnym ciałem i głosem oraz sposobów tworzenia wystąpień jako narzędzi budowania swojego wizerunku publicznego i medialnego. Kolejny, prowadzony przez specjalistę ds. komunikacji reklamowej współpracującego z IFP UAM, to rozbudowana i sprofesjonalizowana propozycja kształcenia umiejętności z zakresu komunikacji reklamowej. Studenci zapoznają się ze specyfiką pracy w agencji reklamowej, poznają podstawowe pojęcia branżowe oraz specyfikę tworzenia ram komunikacji realizujących założenia CI (ang. Corporate Identity), a także zasady budowania klucza pozycjonującego markę i komunikację. Następnie pod kierunkiem prowadzącego przygotowują $\mathrm{w}$ grupach projekty konkretnych komunikatów reklamowych i kampanii reklamowych z uwzględnieniem specyfiki mediów. Blok zajęć praktycznych dopełniony jest cyklem warsztatowym polegającym na praktycznej nauce kreowania wizerunku firmy (instytucji) w mediach społecznościowych (Content marketing). Ponieważ zajęcia te prowadzone są we współpracy z Działem Promocji i Marketingu UAM, studenci mają możliwość wzięcia udziału w działaniach promocyjnych związanych z organizacją corocznego wydarzenia, jakim jest Poznański Festiwal Nauki i Sztuki. Każdy ze studentów odpowiedzialny jest za realizację przydzielonych mu zadań (gromadzenie informacji, wywiady, pisanie tekstów, redakcja i korekta), które po sprawdzeniu przez opiekuna zostają wykorzystane w materiałach festiwalowych. Stają się w ten sposób współodpowiedzialni za sukces (lub porażkę) działań promocyjnych, co jest niewątpliwie czynnikiem najsilniej motywującym ich do rzetelnej i kreatywnej pracy. To także jedno z pierwszych „prawdziwych” doświadczeń zawodowych studentów.

W ostatnim semestrze systematyzowana jest wiedza i praktyczne umiejętności z wcześniejszych etapów kształcenia. Na zajęciach Warsztat mediologa studenci w trakcie praktycznych zajęć z tworzenia i interpretowania zróżnicowanych ze względu na medium oraz sytuację komunikacyjną tekstów kultury ugruntowują kompetencje krytycznej refleksji i analizy praktyk kulturowych. Wcześniejszą wiedzę o budowaniu wizerunku i roli marki uzupełniają kompetencjami z zakresu personal brandingu i sposobów etycznego dbania o markę firmy (Zarządzanie marką). Uczestnicy zdobywają tu podstawowe umiejętności budowania strategii kreowania marki, jej pozycjonowania i doskonalenia. Zapoznają się z technikami planowania kariery i rozwoju, uczą się budowania własnej motywacji, reputacji jako sumy wartości i odpowiedzialności, doskonalą jakość zarządzania sobą i zadaniowością. Rozwijają umiejętność planowania i wywiązywania się z zadań. Zapoznają się również z modelem zarządzania marką, także $\mathrm{w}$ social mediach (analiza SMART i SWOT). Zdobytą wiedzę z zakresu 
kreowania i zarządzania własną marką mają wykorzystywać w sytuacjach szukania pracy, przygotowując własne portfolio i CV.

Tak opracowany program jest efektem wieloletnich doświadczeń dydaktycznych, konsultacji przeprowadzanych z pracodawcami, absolwentami oraz studentami specjalizacji. Przygotowany został z uwzględnieniem standardów kształcenia uniwersyteckiego oraz wymogów uzawodowienia stawianych studiom licencjackim.

Wyposażony w wiedzę filologiczną ( $w$ tym wiedzę o języku, retoryce werbalnej i wizualnej, mechanizmach perswazji i manipulacji) absolwent specjalizacji komunikacja medialna przygotowany jest do pracy zarówno w mediach społecznościowych, agencjach reklamowych, jak i w działach promocji, marketingu, PR, HR firm o dowolnym profilu branżowym, dbających o wysokie standardy etyczne i komunikacyjne w kontaktach z klientami.

\section{Stopień drugi: cyfrowy humanista}

Zmieniająca się współcześnie rola uniwersytetu, zmierzającego w kierunku specjalizacji kształcenia, skłania do sformułowania tezy, że intelektualiści są coraz mniej potrzebni. Tymczasem w kształceniu humanistycznym nie ma prostego przełożenia między posiadaną wiedzą i umiejętnością jej zastosowania. Słusznie zauważyła Daria Hejwosz, badająca rolę współczesnych uniwersytetów w kształtowaniu społecznych elit:

Absolwenci uniwersytetu, wchodząc w świat 'superzłożoności', będą żyli w ciągłej niepewności i wśród wyzwań. Wtedy nie jest tak istotna wiedza na nim zdobyta, ale sposób ich bycia (Hejwosz 2010, 123).

Dlatego celem edukacji specjalizacyjnej na studiach magisterskich jest przygotowanie absolwenta do stawiania czoła wyzwaniom rynku pracy, a nie (tylko) wyuczenie go zawodu.

Michel Foucault już w 1977 roku pisał o odejściu „intelektualisty uniwersalnego”, którego zastąpił „intelektualista wyspecjalizowany”: prawnik, lekarz, inżynier. Intelektualista uniwersalny odwoływał się do ideałów i ponadczasowych wartości, opierał się na ideałach uniwersalności sprawiedliwego prawa, wizji dobrego obywatela. Niezależnie od wykształcenia zajmował się zazwyczaj pisarstwem jako zajęciem stricte intelektualnym, umożliwiającym formułowanie pogłębionych analiz i refleksji na temat najistotniejszych zagadnień dotyczących społeczeństwa i jednostki. Dziś intelektualista działa w określonym sektorze, jest ekspertem, profesjonalistą, specjalistą w określonej dziedzinie (Foucault 1980, 126-127).

Piszący o sytuacji intelektualistów czterdzieści lat później Zygmunt Bauman zauważył, że intelektualista współczesny funkcjonuje na dwóch poziomach. Niższy poziom stanowi słuszność uprawomocniona przez wiedzę, wyższy zaś - skuteczność (know-how) (Bauman 1992, 17). Dziś wyraźnie widać, że często ważniejsze od kompetencji zawodowych okazują się widowiskowość i atrakcyjność argumentów. Bauman powołuje się przy tym 
na Régisa Debraya (Debray 1979), który wskazywał na rosnącą w drugiej połowie XX wieku przewagę mediokratów i menedżerów mediów nad ludźmi wykształconymi. Zjawiska, opisane już w ostatnich dekadach zeszłego wieku, przybrały dziś na sile. W kształceniu uniwersyteckim chodzi zatem o to, by znaleźć złoty środek: kształcąc rzetelnie humanistów, którzy będą pracowali w sferze kreowania i krytyki kultury medialnej, starać się wyposażyć ich w umiejętność atrakcyjnego (tj. skutecznego) wykorzystywania swojej wiedzy i wpływania na jakość przekazów w przestrzeni publicznej. Jakkolwiek trudna może wydawać się ta idea łączenia pragmatyzmu z rzetelnością i intelektualną wszechstronnością, rezygnacja z niej oznaczałaby kres uniwersyteckiej dydaktyki.

Na potrzebę istnienia intelektualistów, obdarzonych „wyobraźnią socjologiczną”3, którzy w dobie specjalizacji nauki będą antycypować „niezamierzone efekty innowacji”, zwraca uwagę zajmująca się filozofią nauki Ewa Bińczyk (Bińczyk 2012). Rozwój refleksji humanistycznej nad postępem technicznym musi pozostać przeciwwagą dla technokracji stanowiącej istotne zagrożenie dla podstaw funkcjonowania zbiorowości. A zatem rzeczywistość, w której magister polonistyki będzie musiał się odnaleźć, wymaga kompetencji dużo szerszych niż tradycyjne filologiczne wykształcenie. Na powiązanie sfery działań twórczych, komunikacyjnych i edukacyjnych z technologią od lat zwracają uwagę sami humaniści, którzy tę nową sytuację nazywają niekiedy „zwrotem cyfrowym" ${ }^{4}$. I chodzi tu nie tylko o proste zastąpienie tradycyjnego warsztatu polonisty narzędziami cyfrowymi ${ }^{5}$. Ta zmiana wymaga oczywiście opanowania praktycznych umiejętności w zakresie obsługi choćby najprostszych programów komputerowych, narzędzi służących do tworzenia witryn i stron internetowych, szablonów blogów czy technik cyfryzacji analogowych tekstów. Równie istotne jednak jest to, że te nowe narzędzia kształtują współczesną komunikację, oddziałują na kształt relacji społecznych i mają charakter kulturotwórczy. Dynamiczne zmiany, jakie zachodzą we współczesności, nie ograniczają się przecież do kolejnych nowinek technologicznych, dotykają samej istoty tego, kim jest człowiek i jak przebiegają jego relacje z otoczeniem. Zmieniają się także środki i sposoby ekspresji artystycznej, przekształceniu

\footnotetext{
${ }^{3}$ Wedle socjologa Charlesa Wrighta Millsa wyobraźnia socjologiczna jest „zdolnością do przechodzenia z jednej perspektywy do innej (...) zdolnością do poruszania się pomiędzy najbardziej bezosobowymi i odległymi przemianami a najbardziej intymnymi przemianami ludzkiej jaźni - i umiejętności dostrzegania związków między jednymi a drugimi." Mills C.W., 2008, Wyobraźnia socjologiczna, Bucholc M. (przeł.), Warszawa, s. 54-55.

4 Por. Zwrot cyfrowy $w$ humanistyce. Internet/ Nowe Media/Kultura 2.0, 2013, Radomski A., Bomba R. (red.), Lublin; tu zwłaszcza cz. 1: Cyfrowe horyzonty nauki oraz cz. 2: Badania i edukacja $w$ kulturze cyfrowej.

5 Takie, wąskie rozumienie proponuje np. Wojciechowski J., W stronę e-humanistyki, 2014, „Forum Akademickie”, nr 12. Podobną definicję podaje M. Maryl w numerze „Tekstów Drugich” poświęconym refleksji nad perspektywami rozwoju refleksji polonistycznej. Por.: „Humanistyka cyfrowa zakłada wykorzystanie komputerów, Internetu i powiązanych technologii, aby umożliwić tworzenie i rozpowszechnianie [sharing] badań humanistycznych na sposoby niedostępne w tradycyjnych praktykach humanistycznych. Humanistyka cyfrowa podważa tradycyjne rozumienie humanistyki, utrzymując interdyscyplinarną współpracę i dostarczając nowych perspektyw dotyczących przedmiotu badań humanistycznych”. Maryl M., 2014, F5: Odświeżanie filologii, „Teksty Drugie”, nr 2, s. 9. (Temat numeru: Nowa(?) filologia).
} 
ulegają poszczególne dziedziny aktywności twórczej i nauki. Zamiast tradycyjnego podziału na dyscypliny, rodzaje sztuk oraz ich gatunki, mamy do czynienia $\mathrm{z}$ transmedialnością oraz rozproszeniem humanistycznych kompetencji, przy rosnącym zapotrzebowaniu na pracowników potrafiących zarządzać wiedzą i informacją. Powstają nowe zawody (jak choćby: researcher, dydaktyk medialny, broker wiedzy, organizator pracy wirtualnej, teletutor, specjalista zarządzania wiedzą, a nawet, bardzo popularny wśród młodego pokolenia, youtuber). Osobny problem stanowi Internet jako nowa rzeczywistość, poszerzająca możliwości działania człowieka we współpracy z maszyną.

Wszystkie te, zasygnalizowane tu jedynie pobieżnie, problemy, stają się przedmiotem zainteresowania i zaangażowania humanistyki. Ponieważ antropologiczną podstawą dla wszystkich ludzkich działań pozostaje język, rozległa przestrzeń zjawisk na pograniczu sztuki słowa, obrazu, multimediów i nowych technologii, w powiązaniu ze współczesnymi problemami wielokulturowości, polityki kulturalnej i społecznej, znaleźć się musi w obrębie uwagi uniwersyteckiej edukacji polonistycznej.

W ramach kształcenia na specjalizacji kultura mediów cyfrowych istotna jest zatem idea humanistyki cyfrowej jako takiej perspektywy rozwoju wiedzy humanistycznej, która problematyzuje wiedzę, otwiera się na nowe technologie i wynikające $\mathrm{z}$ nich możliwości oraz zagrożenia, a także widzi potrzebę współpracy $\mathrm{z}$ dyscyplinami innymi aniżeli tradycyjna filologia.

Kultura mediów cyfrowych to specjalizacja adresowana do absolwentów studiów licencjackich zarówno polonistycznych, jak i innych kierunków. Mile widziani są kulturoznawcy, historycy sztuki, socjologowie, dziennikarze, ale i absolwenci wydziałów artystycznych, medialnych, a nawet uczelni technicznych. Doświadczenie dydaktyczne pokazuje, że taka różnorodność kompetencji, które spotykają się w ramach zajęć specjalizacyjnych, sprzyja otwartości i kreatywności uczestników zajęć. Podstawą edukacyjną pozostaje wiedza o literaturze, języku, kulturze, mediach, teoretycznych ujęciach i sposobach funkcjonalnego wykorzystania posiadanej wiedzy. Przede wszystkim jednak na etapie studiów magisterskich nacisk kładziony jest na pogłębianie i problematyzację wielu zagadnień, na pokazanie perspektyw rozwoju współczesnej humanistyki i budowanie świadomości niewystarczalności i tymczasowości wszelkich rozstrzygnięć. Zawodowa i stosunkowo wąska wiedza ze studiów licencjackich obudowywana jest zatem bardzo różnorodnymi kontekstami po to, by wyposażyć absolwenta w jak najszersze możliwości samorozwoju w miarę zmieniania się potrzeb rynku pracy.

Wykłady, ćwiczenia i warsztaty (łącznie 330 godzin) prowadzą pracownicy Instytutu Filologii Polskiej z Zakładu Literatury i Kultury Nowoczesnej oraz Zakładu Frazeologii i Kultury Języka Polskiego, a także kierunku Media Interaktywne (WFPiK UAM). 


\section{Kultura mediów cyfrowych - siatka zajęć}

Zajęcia rozpoczynają się od systematyzacji wiedzy na temat komunikacji społecznej z uwzględnieniem kontekstów socjologicznych, psychologicznych, ekonomicznych i kulturowych (Teorie i praktyki komunikacji). Przegląd różnych teorii komunikacji pozwala studentowi uzmysłowić sobie sytuacyjność i kontekstowość przyjętych rozwiązań oraz zdać sprawę z możliwości wyboru strategii komunikacyjnej i jej konsekwencji. Wiedza teoretyczna znajduje przełożenie w praktycznym jej zastosowaniu. Studenci muszą podczas ćwiczeń w grupach sami przetestować poznane narzędzia, sprawdzić ich ograniczenia (kulturowe, techniczne, psychologiczne itp.) i możliwości.

W tym samym semestrze odbywa się wykład Medialno-techniczne podstawy kultury. Studenci zdobywają i systematyzują wiedzę na temat roli technologii medialnych w rozwoju kultury i cywilizacji. Wykład jest uzupełnieniem humanistycznej edukacji o ważne z perspektywy współczesnej posthumanistycznej i cybernetycznej kultury konteksty dotyczące związków techniki, maszyn, a także nauk matematycznych z wiedzą antropologiczną.

Poetyka i estetyka nowych mediów to zajęcia warsztatowe, uzupełniające nurt historycznej refleksji na rolą i znaczeniem technologii w kulturze. Zajęcia prowadzone są przez praktyków zajmujących się na co dzień sztuką mediów. Studenci podczas praktycznych zajęć z wykorzystaniem elektronicznych narzędzi (generujących artefakty, przetwarzających gotowe obiekty) mają okazję zapoznać się ze specyfiką i właściwościami interaktywnych obiektów. Zajęcia wpisują się w projekt kształcenia przez doświadczenie: student $\mathrm{w}$ działaniu poznaje właściwości nowych digitalnych zjawisk, staje się ich uczestnikiem i współtwórcą.

W kolejnym semestrze kształcenie nadal przebiega dwoma dopełniającymi się nurtami. Na wykładzie z Historii reprezentacji, łączącym elementy wiedzy filozoficznej i historycznosztucznej, przedstawiona zostaje historia relacji człowiek - obraz - rzeczywistość (człowiek - ekran) od Platona do współczesności. Taka pogłębiona refleksja wyposaża studenta w wiedzę historyczną i pozwala pogłębić rozumienie zjawisk współczesnej kultury, w której symulacja, wirtualne światy i alternatywne rzeczywistości często traktowane są pochopnie jako efekt wyłącznie możliwości technicznych.

Dwa kolejne przedmioty mają charakter warsztatowy. Ćwiczenia z Genologii mediów cyfrowych przynoszą przegląd najnowszych zjawisk w świecie komunikacji medialnej. Lista tych zjawisk jest aktualizowana co roku wspólnie ze studentami, których zadaniem jest krytyczny opis dynamicznie zmieniających się gatunków multimedialnych, połączony z ich testowaniem $\mathrm{w}$ działaniu. Uczestnicy zajęć prowadzą zatem swoje blogi (lub vlogi) poświęcone zagadnieniom nowomedialnym. Projekt, wykonanie i sposób prowadzenia, a także treści zamieszczane w kolejnych wpisach 
są komentowane przez pozostałych uczestników. Wszystkie blogi są także przedmiotem dyskusji i oceny na zajęciach podsumowujących. Studenci realizują także inne, zgodne ze swoimi zainteresowaniami i potrzebami projekty, wykorzystując do tego celu dostępne narzędzia multimedialne. $\mathrm{Na}$ przestrzeni kolejnych lat powstaje modyfikowany na bieżąco słowniczek pojęć, tworzony przez studentów. Wsparcie teoretyczne stanowi kurs e-learningowy, zamieszczony na platformie moodle. Tutaj studenci znajdują instrukcje, materiały teoretyczne i dodatkowe ćwiczenia sprawdzające wiedzę z zakresu podstawowych pojęć i problemów przedmiotu.

Dopełnieniem tych zajęć są ćwiczenia z analizy i tworzenia opowieści. Storytelling jest w tej chwili wszechstronnym narzędziem (rzadziej: metodą badawczą). Często wykorzystywany jako narzędzie marketingowe, służy do podnoszenia sprzedaży produktów i budowania wizerunku osoby, instytucji, firmy, marki. Studentowi filologii polskiej często trzeba jednak uświadomić, jakimi kompetencjami dysponuje i jak może się nimi posługiwać. Dlatego w trakcie warsztatów grupa wykonuje szereg ćwiczeń pisarskich, dzięki którym uczy się, jak wykorzystać filologiczny warsztat (techniki narracyjne, chwyty retoryczne, sztuki angażowania) oraz wiedzę o mechanizmie działania mediów po to, by udoskonalić swoje umiejętności opowiadania w sposób interesujący, przekonujący i skuteczny.

W kolejnym semestrze zajęcia z tworzenia opowieści zostają uzupełnione warsztatem prostej polszczyzny (Optymalizacja kompetencji językowych) prowadzonym przez językoznawcę. Student poznaje najważniejsze mechanizmy prostego języka uwikłanego w konteksty medialne, uczy się funkcjonalnego posługiwania najlepszymi rozwiązaniami komunikacyjnymi. Ćwiczenia dopełniają zajęcia z Kultury komunikacji w mediach cyfrowych.

Specyfikę kultury i sztuki nowych mediów, określanych często już nie cyberkulturą, lecz sztuką postdigitalną, jej związki z tradycją sztuk audiowizualnych, literaturą, fotografią i malarstwem, właściwości i perspektywy rozwoju poznają studenci na ćwiczeniach Korespondencja sztuk w cyberkulturze prowadzonych przez pracownika kierunku Media Interaktywne. Proponowane tu połączenie refleksji teoretycznej z praktyką (zgodne z właściwościami kultury uczestnictwa, która wymaga redukcji dystansu poznawczego) rozwija zarówno myślenie analityczne (jak to jest zrobione? jak to dialoguje z tradycją?), jak i krytyczne.

Ostatni semestr wprowadza jasno określoną perspektywę etyczną do dyskusji nad problemami współczesnej kultury medialnej (Elementy etyki mediów). Zapoznaje studentów z elementami prawnych konsekwencji nadużywania wolności słowa, zwłaszcza w mediach społecznościowych. Natomiast ćwiczenia Gry w kulturze opierają się na szerokim rozumieniu centralnej kategorii gry w ujęciu antropologicznym, ludologicznym, poznawczym i pragmatycznym. W nadchodzących latach w ramach zajęć odbywać się będą warsztaty z zarządzania zespołem i pomiaru swoich 
kompetencji na podstawie gier szkoleniowych przygotowywanych przez Pracownię Gier Szkoleniowych.

\section{Nowoczesny absolwent polonistyki}

W 2012 roku Maria Kwiatkowska-Ratajczak, omawiając rolę i zadania dydaktyki uniwersyteckiej, pisała: „W ramach tej polonistycznej subdyscypliny podstawowe są dwa pytania: „jak...?” i „po co...?” (Kwiatkowska-Ratajczak 2013, 89). Pytania te pozostają wciąż aktualne, przy czym od sposobu, w jaki poradzimy sobie z pierwszym, zależy kształt przyszłego uniwersytetu i - jakkolwiek patetycznie to zabrzmi - jakość przyszłych intelektualnych elit. Nie tylko dlatego, że istnieje konieczność ciągłego dostosowywania sposobów kształcenia do zmieniających się możliwości poznawczych studentów. Także dlatego, że drugie ze wskazanych przez autorkę pytań formułują wprost sami studenci, oczekujący prostego przełożenia wiedzy uniwersyteckiej na praktyczne umiejętności. W tym samym artykule autorka zauważa:

Programy rządowe oczekują od uczelni przygotowania wysoko wykwalifikowanych specjalistów. (...) Nie tylko pracodawcy, lecz także sami studenci niejednokrotnie oczekują recept mających im zapewnić życiowy sukces (Kwiatkowska-Ratajczak 2013, 97).

Kiedy jednak studenci poznają mechanizmy społeczne, ekonomiczne i kulturowe, które powodowały takie ich nastawienie, potrafią zająć postawę krytyczną wobec nich. Wydaje się, że jest to jeden z ważnych elementów przebiegu edukacji akademickiej, gdy postawa oczekiwania na uzyskanie porcji praktycznych wskazówek, zastąpiona stopniowo zostaje procesem autorefleksyjnego zadawania sobie pytań: „w jaki sposób mogę wykorzystać posiadaną wiedzę i umiejętności?”

To zjawisko dobrze ilustruje autentyczne zdarzenie, mające miejsce w Instytucie Filologii Polskiej UAM podczas procesu rekrutacji na specjalizację na drugim stopniu studiów. Jedna z kandydatek, zachęcana do zadawania pytań związanych ze studiowaniem kultury mediów cyfrowych, chciała wiedzieć tylko jedno: czy będzie miała po tej specjalizacji pracę. Opisana sytuacja doskonale uświadamia zadanie stojące przed dydaktykami akademickimi. W ciągu dwóch lat zajęć specjalizacyjnych trzeba przekonać studentów, że to od nich zależy, czy zdobyte kompetencje będą potrafili wykorzystać, aby znaleźć zatrudnienie. Plan kształcenia specjalizacyjnego przygotowany jest we współpracy z pracodawcami, zgłaszającymi swoje potrzeby dotyczące kompetencji pracowników, oraz z absolwentami, którzy po ukończeniu specjalizacji trafili już na rynek pracy i potrafią z perspektywy jego uczestnika wskazać braki w programie, który modyfikowany jest raz na kilka lat. Nie zastąpi to jednak ciężkiej pracy studentów. Uzmysłowienie studiującym, że studia magisterskie nie dają konkretnego zawodu, lecz wyposażają ich w wiedzę i umiejętności, którymi mogą 
samodzielnie zarządzać, dostosowując się do potrzeb rynku pracy, jest często najtrudniejszym zadaniem stojącym przed nauczycielami akademickimi.

Dołożenie starań do tego, by studenci umieli ocenić jakość swoich umiejętności oraz by w kompetencjach nabytych w trakcie kształcenia specjalizacyjnego zobaczyli funkcjonalność wiedzy otwierającej ich myślenie na wyzwania stawiane przez nowoczesny rynek pracy, wydaje się najważniejszym wyzwaniem innowacyjnej polonistyki6.

Wciąż aktualne pozostaje pytanie, jak kształcić, by absolwent już po opuszczeniu murów uniwersytetu potrafił sam rozwijać zdobyte kompetencje w świecie, w którym nie ma jednej prostej drogi prowadzącej do celu, a przypadki realizowane i omawiane na zajęciach warsztatowych różnią się od sytuacji, z którymi będą się stykać w pracy zawodowej.

Nie do przecenienia jest tutaj rola praktyk zawodowych, które często stanowią dla studentów pierwszą obowiązkową, ale jednak odbywającą się w komfortowych warunkach (pod auspicjami uniwersytetu) sytuację konfrontacji swoich wyobrażeń, oczekiwań i faktycznych umiejętności z realiami rynkowymi. Często właśnie wtedy student dowiaduje się, co wie, i uczy się wykorzystywania tej wiedzy w rozwiązywaniu już nie spreparowanych, lecz rzeczywistych problemów. Praktyki studenckie dają więc to, czego żadna forma kształcenia akademickiego nie zapewni. W inscenizowanej sytuacji zadaniowej student zawsze ma poczucie jej „sztuczności”. Poczucie komfortu sprzyja zajmowaniu postawy konformistycznej (po co mam myśleć, skoro to tylko symulacja sytuacji problemowej). Tymczasem praca w firmach i instytucjach, gdzie uczący się musi samodzielne i twórczo wykorzystać posiadane kompetencje, uświadamia mu, że istotnie jego wiedza - tak niekonkretna i niedefiniowalna w porównaniu z np. profesjami technicznymi - ma wartość i zastosowanie. O tym przekonać nie może go żaden wykładowca akademicki.

Program obu specjalności przewiduje odbycie na każdej z nich 90 godzin praktyk zawodowych. Student ma na to cały czas trwania studiów. Praktyki może realizować etapami, w różnych miejscach pracy. Studenci w ramach praktycznego sprawdzenia zdobytych na zajęciach umiejętności (zarządzanie własnym wizerunkiem, autoprezentacja) sami starają się znaleźć dla siebie miejsce praktyk zgodne z profilem kształcenia oraz swoimi preferencjami. W przypadku jakichkolwiek problemów uniwersytecki opiekun praktyk służy pomocą w rozmowach z pracodawcami. Do tej pory nikt nie zgłosił jeszcze potrzeby otrzymania takiego wsparcia. Często natomiast zdarza się, że studenci odbywający praktyki w firmach dają się poznać jako rzetelni, godni zaufania i otwarci na zdobywanie nowych kompetencji pracownicy i po ukończeniu praktyk dostają propozycję pracy.

${ }^{6}$ Tę perspektywę nowej edukacji polonistycznej doskonale oddaje imponujące trzytomowe dzieło, liczące łącznie prawie 1400 stron (!), będące owocem obrad ogólnopolskiego I Kongresu Dydaktyki Polonistycznej, który miał miejsce w 2013 roku na Wydziale Polonistyki UJ; por. Polonistyka dziś kształcenie dla jutra, 2014, t. 1-3, Biedrzycki K., Bobiński W., Janus-Sitarz A., R. Przybylska R. (red.), Kraków. 
Trudno zgodzić się z tym, że dobrze wykształcony polonista, wyposażony w pogłębioną wiedzę o mechanizmach działania mediów, o społecznej oraz interpersonalnej komunikacji, o organizacji i działaniu współczesnej kultury, także w sieci, posiadający umiejętności biegłego posługiwania się w każdej sytuacji funkcjonalnymi stylami polszczyzny mówionej i pisanej, mający wiedzę na temat najnowszych technologii i potrafiący pracować $\mathrm{w}$ zespole ze specjalistami innych dziedzin, jest potencjalnym bezrobotnym.

Na szczęście sami absolwenci najlepiej bronią się przed przyklejeniem im takiej krzywdzącej etykiety. Dość powiedzieć, że z grona kilkudziesięciu studentów, którzy ukończyli w minionych latach jedną (lub obie) spośród prezentowanych tu specjalizacji, wszyscy znaleźli pracę zgodną ze swoim wykształceniem. Pracują w redakcjach czasopism i gazet, agencjach reklamowych, zajmują się kreatywną komunikacją reklamową i copywritingiem, są specjalistami do spraw marketingu i marketingu internetowego, pracują w branży public relations, zarządzają zespołami pracowników, zajmują się doradztwem personalnym, jako specjaliści w dziedzinie komunikacji interpersonalnej uczestniczą $\mathrm{w}$ procesie rekrutacji, prowadzą działania employer branding (budowanie wizerunku pracodawcy), personal branding (specjaliści ds. wizerunku osób) oraz specjalizują się we wdrażaniu nowych narzędzi HR (Human Resourses - zarządzanie zasobami ludzkimi).

Podkreślić przy tym należy, że zawodowe sukcesy naszych absolwentów nie są prostym skutkiem zdobytego na studiach wykształcenia. To wypadkowa ich wiedzy i umiejętności, wrodzonych predyspozycji oraz determinacji i ciężkiej pracy, którą włożyli w to, by dane im możliwości wykorzystać. W koordynacji wszystkich tych czynników kryje się zatem klucz do wspólnego sukcesu uczących i zdobywających wykształcenie. W gruncie rzeczy wszyscy przecież cały czas się uczymy.

\section{Bibliografia:}

Bińczyk Ewa, 2012, Technonauka w społeczeństwie ryzyka. Filozofia wobec niepożadanych następstw praktycznego sukcesu nauki, Toruń.

Bauman Zygmunt, 1992, Miłość wbrew przeciwnościom: intelektualiści a państwo, „Teksty Drugie”, nr 4, s. 7-19.

Debray Régis, 1979, Le pouvoir intellectuel en France, Paris.

Foucault Michel, 1980, Truth and Power, trans. C. Goron, w: Power Knowledge. Selected Interviews and other Writings 1972-1977, Brighton.

Hejwosz Daria, 2010, Edukacja uniwersytecka i kreowanie elit społecznych, Kraków.

Kompetencje Polaków a potrzeby polskiej gospodarki. Raport podsumowujacy IV edycję badań BKL z 2013 r., 2014, Górniak J. (red.), Warszawa.

Kwiatkowska-Ratajczak Maria, 2013, Innowacyjność kształcenia dydaktycznego doktorantów - problemy i perspektywy, w: Nowoczesność w polonistycznej 
eduk@cji: Pytania, problemy, perspektywy, Pilch A., Krysińska M. (red.), Kraków, s. 87-99.

Maryl Maciej, 2014, F5: Odświeżanie filologii, „Teksty Drugie” , nr 2, s. 9-20.

Mills Charles Wright, 2008, Wyobraźnia socjologiczna, Bucholc M. (przeł.), Warszawa, s. 54-55.

Polonistyka dziś - kształcenie dla jutra, 2014, t. 1-3, Biedrzycki K., Bobiński W., Janus-Sitarz A., Przybylska R. (red.), Kraków.

Wojciechowski Jacek, 2014, W stronę e-humanistyki, „Forum Akademickie”, nr 12, s. 32-35.

Zwrot cyfrowy w humanistyce. Internet/Nowe Media/Kultura 2.0, 2013, Radomski A., Bomba R. (red.), Lublin.

\section{O Autorce:}

Elżbieta Winiecka - dr hab., adiunkt w Zakładzie Literatury i Kultury Nowoczesnej IFP UAM. Opiekun specjalizacji komunikacja kulturowa i kultura mediów cyfrowych. Historyk i teoretyk literatury, badaczka poezji polskiej XX wieku. Autorka książek: Białoszewski sylleptyczny (Poznań 2006), Z wnętrza dystansu. Leśmian-Karpowicz-Białoszewski-Miłobędzka (Poznań 2012). Aktualnie zajmuje się przemianami literatury i komunikacji literackiej w Internecie, a także zjawiskiem transmedialności we współczesnej kulturze i sztuce. 
